\title{
Siyer Dersi Öğretim Programının Değerlendirmesi
}

\author{
DOI: 10.26466/opus.614258
}

\author{
Gizem Saygilin - Fatma Songur* \\ * Doç. Dr, Karamanoğlu Mehmetbey Üniversitesi, Eğitim Fakültesi, Karaman / Türkiye \\ E-Posta: gizemsaygili@kmu.edu.tr ORCID: 0000-0002-1787-2492 \\ ** Uzm. Diyanet İşleri Başkanlığı, Isparta Müftülüğü, Isparta / Türkiye \\ E-Posta: fatmasongur@gmail.com \\ ORCID: $\underline{0000-0002-5730-0085}$
}

\section{Öz}

Bu araştırmanın amacı 4+4+4 eğitim sisteminde yer alan Hz. Muhammed'in Hayatı (Siyer) dersine ilişkin öğretmen görüşlerinin inlenmesidir. Bu amaç doğrultusunda 2014 yılında yapılan bu araştırmaya Isparta Il merkezindeki ortaokul ve liselerde görev yapan 73 öğretmen katılmıştır. A raştırmada ölçüt örnekleme seçim modeli kullanılmıştır. Bu bağlamda araştırmaya dahil edilecek öğretmenleri seçerken, ortaokul ve liselerde Siyer Dersi verme durumları dikkate alınmıştır. Isparta Il merkezinde Siyer Dersi veren öğretmenlerin tamamına ulaşılmıştır. Araştırmada veri toplama aracı olarak Çınar (2005) tarafindan geliştirilen "Din Kültürü ve Ahlak Bilgisi Dersine Yönelik Öğretmen Görüşleri", anketinin revize edilmiş hali kullanılmıştır. Araştırmada elde edilen verilerin istatistiksel analizlerinde SPSS paket programında güvenilirlik, yüzde ve frekans analizleri, kullanılmıştır. Araştırmanın sonunda öğretmenlerin Siyer Dersine ilişkin görüşlerinin; öğretim programın amaçları, öğretim programın içeriği, öğretim programın öğretim öğrenim süreci, öğretim programın ölçme ve değerlendirme süreci boyutlarına yönelik olumlu yönde olduğu tespit edilmiştir. Sonuç olarak Siyer Dersinin amaç, içerik, öğretim öğrenim süreci, ölçme ve değerlendirme süreçleri açısından gerekli yeterliliğe sahip olduğu söylenebilir.

Anahtar Kelimeler: 4+4+4 Ĕ̆itim Sistemi, Din eğitimi, Öğretmen Görüşleri, Siyer Dersi, Hz. Muhammed'in Hayatı 


\title{
Evaluation of Siyer Course Teaching Program
}

\begin{abstract}
The aim of this research is $\mathrm{Hz}$. It is the moaning of the opinions of the teachers about Muhammad's Life (Siyer). For this purpose, 73 teachers working in secondary and high schools in Isparta city center participated in this research conducted in 2014. Criteria sampling selection model was used in the research. In this context, while choosing teachers to be included in the research, the situation of teaching Siyer lessons in secondary and high schools was taken into account. All teachers teaching Siyer lessons were reached in Isparta city center. The revised version of the "Teachers' Views on Religious Culture and Moral Knowledge Lesson" developed by Çınar (2005) was used as data collection tool. In statistical analysis of the data obtained in the research, reliability, percentage and frequency analyzes were used in the SPSS package program. At the end of the research, teachers' opinions about the Siyer Lesson; It was determined that the objectives of the curriculum, the content of the curriculum, the curriculum's educational learning process, the curriculum's assessment and evaluation process dimensions were positive. As a result, it can be said that Siyer Course has the necessary proficiency in terms of purpose, content, teaching learning process, measurement and evaluation processes.
\end{abstract}

Keywords: 4+4+4 Education System, Religion Education, Teacher's Opinions, Siyer Lesson, Hz. Muhammed's Life 


\section{Giriş}

Eğitim, toplumların kendi geleceğini planlaması, kurması ve geleceklerine yön vermesi girişimidir. Toplumların geleceklerine verdikleri yön; çağın gereklerine uygun olmak şartıyla toplumun ekonomik, sosyal, siyasal, kültürel ve tarihsel özellikleri dikkate alınarak biçimlendirilir (Çınar, 2003, s.1). Eğitimin temel amacı, öğrencilerin ders kazanımlarıyla entelektüel yeterliliğini geliştirmenin yanında, duyuşsal kazanımlarla karakter gelişimini ve ahlaki yeterliliğini besleyebilmek, bilgiyi yüksek kimlik ve kişilik gelişiminin gerektirdiği düşünce süzgeçlerinden de geçirerek, doğru ve yerinde kullanabilen bir profilin yetişmesine rehber olmaktır. Çünkü iyi eğitim almış bir insan, sadece zihinsel performansı ve kapasitesiyle değil yansıttığı değer yargilarıyla da yaşadığı toplumun aynası durumundadır. Bu da eğitimin yönünü belirleyen program geliştirme faaliyetlerinin, öğrenenin entelektüel bir değer olmanın yanında, sosyal bir değer, bir insan olma mantığının üzerinde temellenmesiyle mümkün olabilir (Kuş, 2009, s.1).

Türkiye' de eğitimde program geliştirme çalışmaları her ne kadar geç başlamış olsa da (Demirel, 1992, s.27), bilgi toplumuna geçiş sürecine paralel olarak, ülkemizde de birçok alanda değişimi zorunlu hale getirmiştir. Bu değişim eğitim alanına da yansımıştır. Türk eğitim sisteminde 2005 yılının ardından 2013 yılında da yeniden yapılandırma yoluna gidilmiş, çağın ihtiyaç ve gerçeklerine uygun insan tipinin yetiştirilmesi için eğitim programları yenilenmiştir. Yeni eğitim programlarının etkilerini ve olumlu yönlerini iyi anlayabilmenin en etkili yolu uygulanan programların değerlendirilmesidir (Yıldırım ve Öztürk, 2009, s.94). Eğitim ve öğretim programı içerisinde öğrencilerin dini ve ahlaki gelişimlerinin sağlanmasında din kültürü ve ahlak bilgisi derslerinin büyük bir önemi vardır. Bu nedenle eğitimde yeniden yapılanma sürecinde ilköğretim ders programının içerisine bazı seçmeli dersler eklenmiştir. Bu seçmeli derslerden birisi de Hz. Peygamber'in hayatıdır. Günümüze kadar aileler çocuklarına Hz. Peygamber'i tanıtmayı ve sevdirmeyi her dönemde amaçlamış ve bunun için çeşitli yollar denemişlerdir. Çocuklarda kitap okumanın zihinsel, duygusal, sosyal ve dini gelişiminde önemli bir yeri olduğu için, bu ihtiyacı kimi zaman çocuklar için hazırlanan siyer kitaplarıyla karşılamaya çalışmışlardır. İnsanın çocukluk yıllarında okuduğu siyer eserleri ömür boyu sahip olacağı peygamber tasavvurunun temelini oluşturmaktadır. Kişinin, hayatının ileriki yıllarında göstereceği dini davranış modelleri 
bu tasavvur üzerine inşa edilir. Bu nedenle siyer eserlerinin azımsanmayacak sayıda arttığı bir dönemde çocuklara rehberlikte bulunurken onlara sunulan bilgiler konusunda dikkatli olunması gerekmektedir (Tursun, 2011, s. 31).

Siyer dersinin ilköğretim ve ortaöğretim müfredatına girmesi ile birlikte bu alanda yapılan yeni düzenlemelerin irdelenmesi, programın işleyiş̧ sistemine ilişkin sorunların ve çözüm önerilerin sunulması, bunların yanında programın amaç, içerik ve uygulanış biçimine ilişkin öğretmen görüşlerinin belirlenmesi oldukça önemli bir konu olarak karşımıza çıkmaktadır. $4+4+4$ eğitim sisteminin getirdiği seçmeli derslerden olan siyer dersinin içeriği, amaçları, eğitim öğretim süreci ve ölçme değerlendirme yapısının iyi bilinmesi, dersin işleyiş biçimindeki aksaklıkların tespit edilmesi söz konusu dersin hedeflerine ulaşma düzeyinin belirlenmesinde büyük öneme sahiptir. $\mathrm{Bu}$ noktada 2013 yılı itibariyle yürürlüğe konulan $4+4+4$ yeni eğitim sistemi içerisinde seçmeli ders olarak işlenen Hz. Peygamber' in hayatına ilişkin konuların öğretmen görüşlerine göre değerlendirilmesi oldukça önemlidir. Özellikle öğrencilerin günlük yaşamlarındaki ahlak ve din anlayışını yakından etkileyen siyer dersinin hem içerik hem de işlenme biçiminin iyi değerlendirilmesi öğrencilerin ahlaki ve dini gelişimlerinin desteklenmesi için gereklidir. Bu bağlamda yapılan bu araştırmada, Isparta ilindeki ilköğretim ve ortaöğretim kurumlarında görev yapan öğretmenlerin siyer dersine yönelik düşüncelerinin bazı değişkenlere göre incelenmesi amaçlanmıştır. Bu kapsamda araştırmaya siyer dersinde programın amaçları, programın içeriği, programın öğrenme öğretme süreci ve ölçme değerlendirme özellikleri hakkındaki öğretmen görüşlerinin bazı değişkenler ışığında incelenmesi amaçlanmıştır.

\section{Yöntem}

\section{Araştırma Modeli}

$\mathrm{Bu}$ araştırmada bilimsel araştırmalarda ve eğitim alanındaki çalışmalarda sıklıkla kullanılan "alan araştırması" yöntemi kullanılmıştır. Eğitim alanında yapılan alan araştırmaları genellikle öğretmenlerin bazı olay veya olgulara ilişkin görüşlerini (Ders konularına bakış açları, konuların işleniş biçimleri hakkındaki görüşleri, eğitim ve öğretim sistemi içindeki sorunlara bakış açıları ve çözüm önerileri) betimlemek için kullanılmaktadır. Araştırmada mo- 
del olarak ise "tarama" modeli kullanılmıştır. Veri toplama işlemlerinde likert tipi ölçek kullanılmıştır. Likert tipi ölçekler ile yapılan tarama modelli araştırmalar da eğitim alanında sıklıkla kullanılmaktadır (Karadağ, 2010, s.63-64). Aynı zamanda tarama modeline dayalı araştırmalar bazı değişkenler ışığında (öğrenim durumu, medeni hal vb.) belirli bir konuya ilişkin özelliklerin belirlenmesi amacı ile sosyal bilimlerde de sıklıkla kullanılmaktadır (Can, 2014, s. 8).

\section{Araştırmanın Evreni ve Örneklemi}

Araştırmaya Isparta il merkezinde bulunan ortaokul, imam hatip ortaokulu, lise ve imam hatip liselerinde görev yapan aynı zamanda siyer derslerine giren toplam 73 öğretmen katılmıştır. Literatürde evren içerisinden örneklem seçiminde bazı yöntemlerin kullanıldığı belirtilmiştir. Ancak evren içerisinden ne kadar yüksek düzeyde örneklem seçilirse elde edilen bulguların evren üzerinde daha etkili bir genelleme yapmaya olanak sağlayacağı ifade edilmiştir. Bu kapsamda eğitim alanında evrende bulunan bireylerin tamamına ulaşmayı amaçlayan birçok çalışma yapılmıştır (Karadağ, 2010, s.55). Yapılan bu araştırmada ölçüt örnekleme seçim modeli kullanılmıştır. Evreni oluşturan tüm öğretmenlere ulaşılması amaçlanmıştır. Isparta İl merkezinde Siyer Dersi veren 80 öğretmenin tamamına ulaşılmıştır.

\section{Veri Toplama Aracı}

Araştırmada veri toplama aracı olarak, Çınar (2005, s.156-159) tarafından geliştirilen “Din Kültürü ve Ahlak Bilgisi Öğretim Programının Değerlendirilmesi" ile ilgili anket sorularının siyer dersine uyarlanmış hali kullanılmıştır. Anketin uyarlanmasında din eğitimi uzmanlarından görüş alınmıştır. Uygulanan anket iki bölümden oluşmaktadır. İlk bölümde araştırmaya katılan öğretmenlerin demografik özelliklerini belirlemeyi amaçlayan 10 soru bulunmaktadır. İkinci bölümde ise öğretmenlerin siyer dersine ilişkin düşüncelerini tespit etmeyi amaçlayan 37 soru bulunmaktadır. Araştırmada siyer dersine ilişkin öğretmen görüşlerinin değerlendirildiği ve 37 sorudan oluşan anket 5'li likert türünde bir ankettir. Sorulardan elde edilen puanların artması öğretmenlerin söz konusu düşünceye katılım oranlarının da arttı̆ını, elde 
edilen puanların düşük olması ise öğretmenlerin söz konusu düşüncelere katılma oranlarının düşük olduğunu göstermektedir. Bunun yanında ankette siyer dersine yönelik 4 boyuta ilişkin sorular yer almaktadır. 1, 2, 3, 4, 5, 6, 7, $8,9,10,11,12$ ve 36 'incı sorular programin amaçları, 15, 16, 17, 21, 22, 24, 25, 26, 27, 29, 33 ve 35'inci sorular programin içeriği, 13, 14, 19, 20, 23 ve 32'inci sorular eğitim ve öğretim süreci, 18, 28, 30, 31 ve 34 'üncü sorular ise programm ölçme ve değerlendirme sürecine ilişkin sorulardan oluşmaktadır. Ders dönemi devam ederken yapılan çalışmamızda, öğretmenlere dağıtılan anket formları, 5 öğretmenimiz tarafından belirlenen süre içerisinde teslim edilmemiştir. 2 anket formu da eksik veri gerekçesi ile analizden çıkartılmıştır. 80 anket formundan 73 tanesi analize dahil edilmiştir. Bu durumda anketin geri dönüş oranı $\% 91,25$ olarak gerçekleşmiştir.

\section{İstatistiksel Analiz}

Araştırmada elde edilen verilerin istatistiksel analizlerinde SPSS programında güvenilirlik ve frekans analizleri, ölçeğin güvenilirliği belirlemek için Cronbach's alfa katsayısı hesaplanmıştır. Ölçekte kullanılan 37 madde için güvenilirlik katsayısı 0.88 olarak elde edilmiştir. Elde edilen bu değer, ölçme aracının yüksek düzeyde güvenilir olduğunu ortaya koymaktadır (Kalaycı, 2008, s.405). Katılımclara ait demografik bilgilerin ve katılımcların siyer dersi hakkındaki sorulara verdikleri yanıtların değerlendirilmesinde frekans analizi kullanılmıştır. Anket sonuçların değerlendirmek için katılımcıların verdikleri cevaplar frekans analizi ile değerlendirilmiştir. Hem demografik sorular hem de öğretmenlerin siyer dersi öğretimine ilişkin sorular frekans analizine tabi tutulmuştur.

\section{Bulgular}

Bu bölümde çalışmaya katılan 73 siyer dersi veren öğretmenin anket formlarından elde edilen bulguların istatiksel sonuçları ve yorumlarına yer verilmiştir. Siyer dersi programının amaçları, programın içeriği, programın öğrenme öğretme süreci ve ölçme değerlendirme özellikleri hakkındaki öğretmen görüşleri aşağıda tablolar halinde sunulmuştur. 
Tablo 1.Katılımcılara Ait Tanımlayıcı İstatistikler

\begin{tabular}{|c|c|c|c|}
\hline Değişkenler & Alt değişkenler & $\mathrm{f}$ & $\%$ \\
\hline \multirow[t]{3}{*}{ Cinsiyet } & Kadın & 14 & 19.2 \\
\hline & Erkek & 57 & 78.1 \\
\hline & Cevapsız & 2 & 2.7 \\
\hline \multirow[t]{5}{*}{ Öğrenim Durumu } & İlahiyat & 54 & 74.0 \\
\hline & Yüksek İslam Enst & 2 & 2.7 \\
\hline & Yüksek Lisans & 12 & 16.4 \\
\hline & Diğer & 2 & 2.7 \\
\hline & Cevapsiz & 3 & 4.1 \\
\hline \multirow[t]{3}{*}{ Medeni Durum } & Evli & 68 & 93.2 \\
\hline & Bekâr & 1 & 1.4 \\
\hline & Boşanmış & 1 & 1.4 \\
\hline \multirow[t]{8}{*}{ Mesleki Deneyim } & $0-5 Y_{11}$ & 1 & 1.4 \\
\hline & 6-10 Yil & 15 & 20.5 \\
\hline & 11-15 Y 11 & 11 & 15.1 \\
\hline & $16-20 Y_{11}$ & 14 & 19.2 \\
\hline & 21-25 Y1l & 12 & 16.4 \\
\hline & 26-30 Yll & 9 & 12.3 \\
\hline & 30 ve Üzeri & 8 & 11.0 \\
\hline & Cevapsız & 3 & 4.1 \\
\hline \multirow[t]{5}{*}{ Görev Yapılan Kurum } & Ortaokul & 31 & 42.5 \\
\hline & Lise & 23 & 31.5 \\
\hline & İmam Hatip Ortaokul & 6 & 8.2 \\
\hline & İmam Hatip Lisesi & 10 & 13.7 \\
\hline & Cevapsız & 3 & 4.1 \\
\hline \multirow[t]{6}{*}{ Ekonomik Durumu } & Çok İyi & 1 & 1.4 \\
\hline & İyi & 28 & 38.4 \\
\hline & Orta & 37 & 50.7 \\
\hline & Düşük & 3 & 4.1 \\
\hline & Çok Düşük & 1 & 1.4 \\
\hline & Cevapsiz & 3 & 4.1 \\
\hline \multirow[t]{5}{*}{ İdari Görev } & Müdür & 1 & 1.4 \\
\hline & Müdür Yardımcısı & 6 & 8.2 \\
\hline & Diğer & 2 & 2.7 \\
\hline & Yok & Yok & 83.6 \\
\hline & Cevapsiz & 3 & 4.1 \\
\hline
\end{tabular}

Tablo 1, katılımclara ait 7 tanımlayıcı istatistiki bilgiyi sunmaktadır. Bu bağlamda katılımcların cinsiyetlerine göre dağılımları incelendiğinde, araştırmaya katılan Siyer öğretmenlerinin \%78.1 gibi büyük bir çoğunluğunun erkek öğretmenlerden oluştuğu, kadın öğretmenlerin oranının ise, \%19.2 gibi oldukça az bir kitleyi teşkil ettiği görülmektedir. Katılımcıların mesleki k1dem yıllarına göre dağılımları incelendiğinde, öğretmenlerin \%1.4'ünün mesleki k1demlerinin 1-5 yıl, \%20.5' inin 6-10 yıl, \%15,1'inin 11-15 yıl, \%19.2'sinin 16-20 yıl, \%16,4'ünün 21-25 yıl, \%12,3'ünün 26-30 yıl ve \%11'inin ise 30 yıl 
ve üzeri mesleki kıdeme sahip oldukları anlaşılmaktadır. Katılımcıların öğrenim durumlarına göre dağılımları incelendiğinde, öğretmenlerin \%74'ünün ilahiyat fakültesi mezunu oldukları, \%2.7'sinin yüksek lisans, \%16.4'ünün Yüksek İslam Enstitüsü, \%2.7'inin ise diğer yükseköğretim kurumlarından mezun oldukları öğrenilmektedir. Katılımcıların ekonomik gelir düzeylerine göre dağılımları incelendiğinde, öğretmenlerin \%50.7'sinin ekonomik durumunun orta düzey olduğu, \%38.4'ünün iyi, \%4.1'inin düşük, \%1.4'ünün çok yüksek, \%1.4'ünün ise çok düşük olduğu anlaşılmaktadır. Katılımclların medeni durumlarına göre dağılımları incelendiğinde, öğretmenlerin \%93.2'sinin evli, \%1.4'ünün bekar, \%1.4'ünün ise boşanmış olduğu görülmektedir. Araştırmaya katılan öğretmenlerin görev yaptıkları kurumlara göre dağılımları incelendiğinde, öğretmenlerin \%42.5'inin ortaokul, \%31.5'inin lisede, $\% 13.7$ 'sinin imam hatip lisesinde ve $\% 8.2$ 'sinin imam hatip ortaokulunda görev yaptıkları bilinmektedir. Araştırmaya katılan öğretmenlerin idari görev yapma durumlarına göre dağılımları incelendiğinde, öğretmenlerin \%83.6's1nın çalıştıkları kurumlarda herhangi bir idari görevlerinin bulunmadığı, \%8.2'sinin müdür yardımcısı olduğu, \%2.7'sinin diğer idari görevlerde bulundukları, \%1.4'ünün ise müdür olarak görev yaptıkları anlaşılmaktadır.

\section{Tablo 2. Katılımcılarn Siyer Dersinde Programın Amaçlarına İlişkin Görüşleri}

\begin{tabular}{llllll}
\hline Iffadeler & & & & & \\
& & &
\end{tabular}




\begin{tabular}{|c|c|c|c|c|c|c|}
\hline \multirow{2}{*}{$\begin{array}{l}\text { Eğitim araç-gereç eksikliği, amaçlara tam olarak ulaşılama- } \\
\text { masının en önemli sebebidir. }\end{array}$} & $f$ & 4 & 15 & 11 & 36 & 7 \\
\hline & $\%$ & 5.5 & 20.5 & 15.1 & 49.3 & 9.6 \\
\hline \multirow{2}{*}{$\begin{array}{l}\text { Siyer ders saatinin yetersizliği amaçlara tam olarak ulaşıla- } \\
\text { mamasının en önemli sebebidir. }\end{array}$} & $f$ & 6 & 23 & 8 & 25 & 11 \\
\hline & $\%$ & 8.2 & 31.5 & 11.0 & 34.2 & 15.1 \\
\hline \multirow{2}{*}{$\begin{array}{l}\text { Diğer derslerle ve çevreyle dersin bütünleşmemesi amaç- } \\
\text { lara tam olarak ulaşılamamasının en önemli sebebidir. }\end{array}$} & $f$ & 5 & 28 & 8 & 26 & 6 \\
\hline & $\%$ & 6.8 & 38.4 & 11.0 & 35.6 & 8.2 \\
\hline \multirow[t]{2}{*}{ Uygulanan müfredat hedeflerle tutarlıdır. } & $f$ & 4 & 18 & 12 & 31 & 8 \\
\hline & $\%$ & 5.5 & 24.7 & 16.4 & 42.5 & 11.0 \\
\hline
\end{tabular}

Tablo 2, katılımcların siyer dersinde programın amaçlarına ilişkin görüşlerini 12 madde halinde ortaya koymaktadır. Buna göre konuların anlaşılabilirlik düzeyine ilişkin öğretmen görüşleri incelendiğinde, "Siyer dersi programı, konuların anlaşılması hususunda yeterlidir" düşüncesine öğretmenlerin \%39.7'sinin katılmadığı, \%38.4'ünün kesinlikle katılmadığı, \%12.3'ünün bu konuda kararsız olduğu ve \%5.5'inin katıldığı görülmektedir. Amaçların anlaşılabilirlik seviyesine ilişkin öğretmen görüşleri incelendiğinde, "Siyer dersinin amaçları programda açık ve anlaşılır bir dille ifade edilmiştir" düşüncesine öğretmenlerin \%56.2'sinin katıldığı, \%27.4'ünün katılmadığı, \%6.8'inin kesinlikle katıldığı, \%5.5'inin kesinlikle katılmadığ1 tespit edilmiştir. Öğretmenlerin \%4.1'inin ise bu düşünceye katılma konusunda kararsız olduğu sonucuna ulaşılmıştır. Amaçların öğrenci davranışı kazandırma ve geliştirme düzeyine ilişkin öğretmen görüşleri incelendiğinde, "Siyer dersinin amaçları öğrenci davranışı kazandırma ve geliştirme yönünden yeterlidir" düşüncesine öğretmenlerin \%64.4'ünün katıldığı, \%11'inin katılmadığı, \%6.8'inin kesinlikle katıldığı, \%2.7'sinin de kesinlikle katılmadığı tespit edilmiştir. Bu düşünceye katılma konusunda kararsız olan öğrencilerin oranının ise \%15.1 olduğu tespit edilmiştir. Mevcut programın amaçları gerçekleştirme düzeyine ilişkin öğretmen görüşleri incelendiğinde, "Siyer dersinin mevcut programı bu dersin amaçlarını gerçekleştirebilecek düzeydedir" düşüncesine öğretmenlerin \%43.8'inin katıldığı, \%24.7'sinin katılmadığı, \%8.2'sinin kesinlikle katıldığı, \%5.5' inin ise kesinlikle katılmadığ 1 tespit edilmiştir. Öğretmenlerin \%17.8'inin de bu düşünceye katılma konusunda kararsız oldukları tespit edilmiştir. Amaçların gerçekleşme düzeyine ilişkin öğretmen görüşleri incelendiğinde; "Siyer dersinin amaçları tam olarak gerçekleşmektedir" düşüncesine öğretmenlerin \%38.4'ünün katıldıkları, \%21.9'unun katılmadığı, \%9.6'sının kesinlikle katıldığı ve \%9.6'sının kesinlikle katılma- 
dığ1 tespit edilmiştir. Bu düşünceye katılma konusunda kararsız olan öğretmenlerin oranının ise \%20.5 olduğu tespit edilmiştir. Amaçların gerçekleşmemesinin nedenlerine ilişkin öğretmen görüşleri incelendiğinde, "Siyer dersinin amaçlarının iyi belirlenmemesi, amaçlara tam olarak ulaşılamamasının en önemli sebebidir" düşüncesine katılma konusunda öğretmenlerin \%31.5'inin kararsız olduğu, öğretmenlerin \%30.1'inin bu düşünceye katıldığı, \%26'sının katılmadığı, \%9.6' sinın kesinlikle katılmadığı, \%2.7'sinin ise kesinlikle katıldığ1 tespit edilmiştir. Okul aile ve çevrenin tutumuna ilişkin öğretmen görüşleri incelendiğinde, "Okul, aile ve çevreden kaynaklana faktörler, amaçlara tam olarak ulaşılamamasının en önemli sebebidir" düşüncesine öğretmenlerin \%42.5' inin katıldığı, \%15.1'inin kesinlikle katıldığı, \%17.8'inin katılmadığı, \%5.5'inin ise kesinlikle katılmadığı tespit edilmiştir. Öğretmenlerin \%19.2'sinin ise bu düşünceye katılma konusunda kararsız oldukları belirlenmiştir. Özel öğretim yöntemlerinin uygulanmayışına ilişkin öğretmen görüşleri incelendiğinde, "Siyer dersinde özel öğretim yöntemlerinin uygulanmayışı, amaçlara tam olarak ulaşılamamasının en önemli sebebidir" düşüncesine öğretmenlerin \%53.4'ünün katıldığı, \%20.5'inin kesinlikle katıldığı, \%9.6'sının katılmadığı, \%5.5'inin ise kesinlikle katılmağı tespit edilmiştir. $\mathrm{Bu}$ düşünceye katılma konusunda kararsız olan öğretmenlerin oranının ise \%11 olduğu tespit edilmiştir. Eğitim araç gereç eksikliğine ilişkin öğretmen görüşleri incelendiğinde, "Eğitim araç gereç eksikliği, amaçlara tam olarak ulaşılamamasının en önemli sebebidir" düşüncesine öğretmenlerin \%49.3'ünün katıldıkları, \%20.5'inin katılmadığı, \%9.6'sının kesinlikle katıldığı ve \%5.5'inin kesinlikle katılmadığı tespit edilmiştir. Öğretmenlerin \%15.1'inin bu düşünceye katılma konusunda kararsız olduğu belirlenmiştir. Ders saatinin yetersizliğine ilişkin öğretmen görüşleri incelendiğinde, "Siyer ders saatinin yetersizliği amaçlara tam olarak ulaşılamamasının en önemli sebebidir" düşüncesine öğretmenlerin \%34.2'sinin katıldığı, \%31.5'inin katılmadığı, \%15.1'inin kesinlikle katıldığ1, \%8.2'sinin de kesinlikle katılmadığı tespit edilmiştir. Bunun yanında öğretmenlerin \%11'inin bu düşünceye katılma konusunda kararsız oldukları belirlenmiştir. Diğer derslerle ve çevreyle dersin bütünleşmemesine ilişkin öğretmen görüşleri incelendiğinde, "Diğer derslerle ve çevreyle dersin bütünleşmemesi amaçlara tam olarak ulaşılamamasının en önemli sebebidir" düşüncesine öğretmenlerin \%38.4'ünün katılmadığı, \%35.6'sının katıldığı, \%8.2'sinin kesinlikle katıldığı, \%6.8'inin ise kesinlikle 
katılmadığı belirlenmiştir. Ayrıca öğretmenlerin \%11'inin bu düşünceye katılma konusunda kararsız oldukları tespit edilmiştir. Müfredatın amaçlarla tutarlılık düzeyine ilişkin öğretmen görüşleri incelendiğinde, “Uygulanan müfredat hedeflerle tutarlıdır" düşüncesine öğretmenlerin \%42.5'inin katıldığı, \%24.7'sinin katılmadığı, \%11'inin kesinlikle katıldığı, \%5.5'inin ise kesinlikle katılmadığı tespit edilmiştir. Bu düşünceye katılma konusunda kararsız olan öğretmenlerin oranının ise \%16.4 olduğu tespit edilmiştir.

Tablo 3. Katılımcıların Siyer Dersinde Programın İçeriğine İlişkin Görüşleri

\begin{tabular}{|c|c|c|c|c|c|c|}
\hline Iffadeler & & 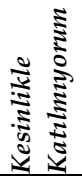 & 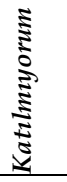 & 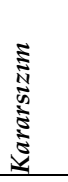 & $\underset{\frac{\sqrt{5}}{5}}{\frac{\pi}{5}}$ & 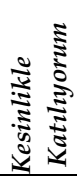 \\
\hline \multirow{2}{*}{$\begin{array}{l}\text { Siyer dersi programı Hz. Muhammed'in hayatını } \\
\text { günlük hayata yansıtarak daha bilinçli bireyler yetiş- } \\
\text { tirilmesine yönelik hazırlanmıştır. }\end{array}$} & $f$ & 3 & 8 & 9 & 40 & 13 \\
\hline & $\%$ & 4.1 & 11.0 & 12.3 & 54.8 & 17.8 \\
\hline \multirow{2}{*}{$\begin{array}{l}\text { Siyer dersinde okutulan müfredat ögrencilerin yaş } \\
\text { düzeyine uygundur. }\end{array}$} & $f$ & 1 & 9 & 7 & 46 & 10 \\
\hline & $\%$ & 1.4 & 12.3 & 9.6 & 63.0 & 13.7 \\
\hline \multirow{2}{*}{$\begin{array}{l}\text { Programda konuların sıralanışında "kolaydan zora" } \\
\text { "basitten karmaşı̆ga" "somuttan soyuta" gibi öğretim } \\
\text { ilkelerine dikkat edilmiştir. }\end{array}$} & $f$ & 3 & 6 & 7 & 49 & 8 \\
\hline & $\%$ & 4.1 & 8.2 & 9.6 & 67.1 & 11.0 \\
\hline \multirow{2}{*}{$\begin{array}{l}\text { Siyer dersi programı öğrencilerin, akılı ve eleştirel bir } \\
\text { yaklaşım geliştirmelerine olanak tanımaktadır. }\end{array}$} & $f$ & 6 & 13 & 14 & 35 & 5 \\
\hline & $\%$ & 8.2 & 17.8 & 19.2 & 47.9 & 6.8 \\
\hline \multirow{2}{*}{$\begin{array}{l}\text { Siyer dersi programına eklenmesi gereken ünite veya } \\
\text { konular bulunmaktadır. }\end{array}$} & $f$ & 9 & 18 & 5 & 36 & 5 \\
\hline & $\%$ & 12.3 & 24.7 & 6.8 & 49.3 & 6.8 \\
\hline \multirow{2}{*}{$\begin{array}{l}\text { Siyer dersi programı, görsel yöntemlerin etkili kulla- } \\
\text { nılmasına uygun hazırlanmıştır. }\end{array}$} & $f$ & 11 & 17 & 12 & 31 & 2 \\
\hline & $\%$ & 15.1 & 23.3 & 16.4 & 42.5 & 2.7 \\
\hline \multirow{2}{*}{$\begin{array}{l}\text { Siyer dersi programı, sözel yöntemlerin etkili kullanıl- } \\
\text { masına uygun hazırlanmıştır. }\end{array}$} & $f$ & 3 & 6 & 12 & 40 & 12 \\
\hline & $\%$ & 4.1 & 8.2 & 16.4 & 54.8 & 16.4 \\
\hline \multirow{2}{*}{$\begin{array}{l}\text { Öğretmenler mevcut araç gereçleri etkili bir şekilde } \\
\text { kullanabilmektedir. }\end{array}$} & $f$ & 4 & 15 & 12 & 36 & 6 \\
\hline & $\%$ & 5.5 & 20.5 & 16.4 & 49.3 & 8.2 \\
\hline \multirow{2}{*}{$\begin{array}{l}\text { Siyer dersi programı, öğrencilerin derse ilgilerini sağ- } \\
\text { lamaktadır. }\end{array}$} & $f$ & 2 & 7 & 6 & 47 & 11 \\
\hline & $\%$ & 2.7 & 9.6 & 8.2 & 64.4 & 15.1 \\
\hline \multirow{2}{*}{$\begin{array}{l}\text { Programda yer alan konular, öğrencilerin Siyer dersi } \\
\text { konusunda tüm ihtiyaçlarına cevap verecek şekilde } \\
\text { hazırlanmıştır. }\end{array}$} & $f$ & 4 & 8 & 14 & 44 & 3 \\
\hline & $\%$ & 5.5 & 11.0 & 19.2 & 60.3 & 4.1 \\
\hline \multirow{2}{*}{$\begin{array}{l}\text { Siyer dersi programı öğrencilerin ahlaki davranışlar } \\
\text { kazanmasında etkilidir. }\end{array}$} & $f$ & 7 & 15 & 19 & 30 & 2 \\
\hline & $\%$ & 9.6 & 20.5 & 26.0 & 41.1 & 2.7 \\
\hline \multirow{2}{*}{$\begin{array}{l}\text { Siyer dersinde Hz. Muhammed'in hayatı, günlük ya- } \\
\text { şantısı, ahlaki özellikleri gibi konulara yer verilmesi } \\
\text { lise programda yer alması açısından uygundur. }\end{array}$} & $f$ & 6 & 8 & 11 & 38 & 10 \\
\hline & & 8.2 & 11.0 & 15.1 & 52.1 & 13.7 \\
\hline
\end{tabular}


Tablo 3, katılımcıların siyer dersinde programın içeriğine ilişkin görüşlerini 12 madde halinde ortaya koymaktadır. Buna göre, müfredat ile bilinçli bireyler yetişmesine ilişkin öğretmen görüşleri incelendiğinde, "Siyer dersi programı Hz. Muhammed'in hayatını günlük hayata yansıtarak daha bilinçli bireyler yetiştirilmesine yönelik hazırlanmıştır" düşüncesine öğretmenlerin \%54.8'inin katıldığı, \%17.8'inin kesinlikle katıldığı, \%11'inin katılmadığı, \%4.1'inin ise kesinlikle katılmadığı tespit edilmiştir. Ayrıca öğretmenlerin \%12.3'ünün bu düşünceye katılma konusunda kararsız olduğu belirlenmiştir. İçeriğin öğrencilerin yaş düzeyine uygunluğuna ilişkin öğretmen görüşleri incelendiğinde, "Siyer dersinde okutulan müfredat öğrencilerin yaş düzeyine uygundur" düşüncesine öğretmenlerin \%63'ünün katıldığı, \%13.7'sinin kesinlikle katıldıkları, \%12.3'ünün katılmadığı, \%1.4'ünün ise kesinlikle katılmadığı tespit edilmiştir. Öğretmenlerin \%9.6'sının bu düşünceye katılma konusunda kararsız oldukları belirlenmiştir. İçeriğin aşamalılık ve önkoşul ilkesine uygunluğuna ilişkin öğretmen görüşleri incelendiğinde, Programda konuların sıralanışında "kolaydan zora" "basitten karmaşığa" "somuttan soyuta" gibi öğretim ilkelerine dikkat edilmiştir, düşüncesine öğretmenlerin \%67.1'inin katıldığı, \%11'inin kesinlikle katıldığı, \%8.2'sinin katılmadığı, \%4.1'inin ise kesinlikle katılmadığı tespit edilmiştir. Öğretmenlerin \%9.6's1nın bu düşünceye katılma konusunda kararsız oldukları belirlenmiştir. İçeriğin öğrencilerde düşünme yeteneğini geliştirme düzeyine ilişkin öğretmen görüşleri incelendiğinde, "Siyer dersi programı öğrencilerin, akılcı ve eleştirel bir yaklaşım geliştirmelerine olanak tanımaktadır" düşüncesine öğretmenlerin \%47.9'unun katıldığı, \%17.8'inin katılmadığı, \%8.2'sinin kesinlikle katılmadığı, \%6.8'inin ise kesinlikle katıldığ1 tespit edilmiştir. Öğretmenlerin \%19.2'sinin bu düşünceye katılma konusunda kararsız oldukları belirlenmiştir. İçeriğe eklenmesi gereken ünite ve konulara ilişkin öğretmen görüşleri incelendiğinde, "Siyer dersi programına eklenmesi gereken ünite veya konular bulunmaktadır" düşüncesine öğretmenlerin \%49.3'ünün katıldığ1, \%24.7'sinin katılmadığı, \%12.3'ünün kesinlikle katılmadığı, \%6.8'inin ise kesinlikle katıldığı tespit edilmiştir. Öğretmenlerin \%6.8'inin bu düşünceye katılma konusunda kararsız oldukları belirlenmiştir. Programın görsel yöntemlerin etkili kullanılmasına uygun hazırlamış olması durumuna ilişkin öğretmen görüşleri incelendiğinde, "Siyer dersi programı, görsel yöntemlerin etkili kullanılmasına uygun hazırlanmıştır" düşüncesine öğretmenlerin \%42.5'inin katıldığı, \%23.3'ünün katılmadığı, \%15.1'inin kesinlikle katılmadığ1, \%2.7'sinin 
ise kesinlikle katıldığı tespit edilmiştir. Öğretmenlerin \%16.4'ünün bu düşünceye katılma konusunda kararsız oldukları belirlenmiştir. Programın sözel yöntemlerin etkili kullanılmasına uygun hazırlanmış olması durumuna ilişkin öğretmen görüşleri incelendiğinde, "Siyer dersi program1, sözel yöntemlerin etkili kullanılmasına uygun hazırlanmıştır" düşüncesine öğretmenlerin \%54.8'inin katıldığı, \%16.4'ünün kesinlikle katıldığı, \%8.2'sinin katılmadığı ve \%4.1'inin kesinlikle katılmadığı tespit edilmiştir. Öğretmenlerin \%16.4'ünün bu düşünceye katılma konusunda kararsız oldukları belirlenmiştir. Öğretmenlerin eğitim araç gereçleri kullanabilme becerilerine ilişkin öğretmen görüşleri incelendiğinde, "Öğretmenler mevcut araç gereçleri etkili bir şekilde kullanabilmektedir" düşüncesine öğretmenlerin \%49.3'ünün katıldığ sinlikle katılmadığı tespit edilmiştir. Öğretmenlerin \%16.4'nün bu düşünceye katılma konusunda kararsız oldukları belirlenmiştir. İçeriğin öğrencilerin ilgisini çekme düzeyine ilişkin öğretmen görüşleri incelendiğinde, "Siyer dersi programı, öğrencilerin derse ilgilerini sağlamaktadır" düşüncesine öğretmenlerin \%64.4'ünün katıldığı, \%9.6'sının katılmadığı, \%15.1'inin kesinlikle katıldığı, \%2.7'sinin ise kesinlikle katılmadığı tespit edilmiştir. Öğretmenlerin \%8.2'sinin bu düşünceye katılma konusunda kararsız oldukları belirlenmiştir. İçeriğin öğrencilerin dini konulardaki tüm ihtiyaçlarına karşılık verme düzeyine ilişkin öğretmen görüşleri incelendiğinde, "Programda yer alan konular, öğrencilerin Siyer dersi konusunda tüm ihtiyaçlarına cevap verecek şekilde hazırlanmıştır" düşüncesine öğretmenlerin \%60.3'ünün katıldığı, \%11'inin katılmadığı, \%5.5'inin kesinlikle katılmadığı ve \%4.1'inin kesinlikle katıldığ1 tespit edilmiştir. Öğretmenlerin \%19.2'sinin bu düşünceye katılma konusunda kararsız oldukları belirlenmiştir. İçeriğin ahlaki davranış kazandırma düzeyine ilişkin öğretmen görüşleri incelendiğinde, "Siyer dersi programı öğrencilerin ahlaki davranışlar kazanmasında etkilidir" düşüncesine öğretmenlerin \%41.1'inin katıldığı, \%20.5'inin katılmadığı, \%9.6'sının kesinlikle katılmadığı ve \%2.7'sinin kesinlikle katıldığı tespit edilmiştir. Öğretmenlerin \%26'sının bu düşünceye katılma konusunda kararsız oldukları belirlenmiştir. Siyer derslerinin ortaokul ve liselerde yer alması gerektiğine ilişkin öğretmen görüşleri incelendiğinde, "Siyer dersinde Hz. Muhammed'in hayatı, günlük yaşantısı, ahlaki özellikleri gibi konulara yer verilmesi lise programda yer alması açısından uygundur" görüşüne öğretmenlerin \%52.1'inin katıl- 
dığı, \%13.7'sinin kesinlikle katıldığı, \%11'inin katılmadığ sinlikle katılmadığı tespit edilmiştir. Öğretmenlerin \%15.1'inin bu düşünceye katılma konusunda kararsız oldukları belirlenmiştir.

Tablo 4. Katılımcıların Siyer Dersine İlişkin Ĕ̆itim ve Öğretim Süreci Hakkındaki Görüşleri

\begin{tabular}{llllll}
\hline Ifadeler & & &
\end{tabular}

Tablo 4, katılımcıların siyer dersine ilişkin eğitim ve öğretim süreci hakkındaki görüşlerini 8 madde halinde ortaya koymaktadır. Bu bağlamda öğretmenlerin, programın uygulanabilirlik düzeyine ilişkin öğretmen görüşleri incelendiğinde, "Programın uygulaması için siyer dersinin haftalık ders saati yeterlidir" düşüncesine öğretmenlerin \%53.4'ünün katıldığı, \%24.7'sinin katılmadığı, \%12.3'ünün kesinlikle katıldığg, \%5.5' inin ise kesinlikle katılmadığ1 tespit edilmiştir. Öğretmenlerin \%4.1'inin bu düşünceye katılma konusunda kararsız oldukları belirlenmiştir. Eğitim öğretim süreçlerinde eğitim araç gereçlerin bulunabilirlik düzeyine ilişkin öğretmen görüşleri incelendiğinde, “Ders işlenirken dersin öğretimi ile ilgili yeterli araç gereç temin edilebilmektedir" düşüncesine öğretmenlerin \%52.1'inin katıldığı, \%27.4'ünün katılmadığı, \%8.2'sinin kesinlikle katıldığı, \%4.1'inin ise kesinlikle katılmadığı tespit 
edilmiştir. Öğretmenlerin \%8.2'sinin bu düşünceye katılma konusunda kararsız oldukları belirlenmiştir. İlkeler arasında birbiriyle çelişen hususların bulunmasına ilişkin öğretmen görüşleri incelendiğinde, "Siyer ders öğretiminin ilkeleri arasında, birbiriyle çelişen hususlar vardır" düşüncesine öğretmenlerin \%42.5'inin katıldığı, \%17.8'inin katılmadığı, \%8.2'sinin kesinlikle katıldığ 1 ve \%5.5'inin kesinlikle katılmadığ 1 tespit edilmiştir. Öğretmenlerin \%26'sının bu düşünceye katılma konusunda kararsız oldukları belirlenmiştir. Örnek işlenişler hakkındaki öğretmen görüşleri incelendiğinde, "Siyer dersinin öğreticilere tanıtılması hususunda ek eserlerin, örnek ders işlenişlerinin hazırlanması faydalı olmuştur" düşüncesine öğretmenlerin \%56.2' sinin katılmadığı, \%12.3'ünün katıldığı, \%13.7'sinin kesinlikle katılmadığı ve \%4.1'inin kesinlikle katıldığ tespit edilmiştir. Öğretmenlerin \%13.7'sinin bu düşünceye katılma konusunda kararsız oldukları belirlenmiştir. Programda ünite ve içeriklerin birbirine paralel ve bütünleyici bir şekilde hazırlanmasına ilişkin öğretmen görüşleri incelendiğinde, "Siyer dersi programında, ünite ve içerikler birbirine paralel ve bütünleyici bir şekilde hazırlanmıştır" düşüncesine öğretmenlerin \%49.3'ünün katıldığı, \%19.2'sinin katılmadığı, \%6.8'inin kesinlikle katıldığ 1 ve \%4.1'inin kesinlikle katılmadığ tespit edilmiştir. Öğretmenlerin \%20.5'inin bu düşünceye katılma konusunda kararsız oldukları belirlenmiştir. İçeriğin güncel ve yaşanan hayata uygun olma düzeyine ilişkin öğretmen görüşleri incelendiğinde, "Siyer dersi programı, güncel ve yaşanan hayata uygun şekilde hazırlanmıştır" düşüncesine öğretmenlerin \%52.1'inin katıldığı, \%15.1'inin katılmadığı, \%8.2'sinin kesinlikle katılmadığı, \%6.8'inin kesinlikle katıldığı tespit edilmiştir. Öğretmenlerin \%17.8'inin bu düşünceye katılma konusunda kararsız oldukları belirlenmiştir. Programın zaman itibariyle uygulanabilirlik düzeyine ilişkin öğretmen görüşleri incelendiğinde, "Siyer dersinin müfredatı, belirlenen zaman süresi içinde tamamlanabilecek düzeydedir" düşüncesine öğretmenlerin \%74'ünün katıldığı, \%9.6'sının katılmadığı, \%6.8' inin kesinlikle katıldığ ve \%6.8' inin kesinlikle katılmadığı tespit edilmiştir. Öğretmenlerin \%2.7'sinin bu düşünceye katılma konusunda kararsız oldukları belirlenmiştir. Ders uygulamasında farklı kaynaklara temasın sağlanmasına ilişkin öğretmen görüşleri incelendiğinde, "Siyer dersi programı, öğrencilerimizin farklı kaynaklarla temaslarını sağlamaktadır" düşüncesine öğretmenlerin \%68.5'inin katıldığı, \%11'inin katılmadığı, \%9.6's1nın kesinlikle katıldığı, \%2.7'sinin ise kesinlikle katılmadığı tespit edilmiştir. 
Öğretmenlerin \%8.2'sinin bu düşünceye katılma konusunda kararsız oldukları belirlenmiştir.

Tablo 5. Siyer Dersinde Ölçme ve Değerlendirmeye İlişkin Öğretmen Görüşleri

\begin{tabular}{lllllll}
\hline Iffadeler & & & \\
& &
\end{tabular}

Tablo 5, katılımcların siyer dersinde ölçme ve değerlendirmeye ilişkin öğretmen görüşlerini 5 madde halinde ortaya koymaktadır. Bu bağlamda, uygulanan değerlendirme tekniklerinin amaçların kazanılma durumunu ölçme düzeyine ilişkin öğretmen görüşleri incelendiğinde, "Uygulanan değerlendirme yöntemleriyle programda hedeflenen amaçlara ulaşıp ulaşılmadığ 1 tam olarak ölçülebilmektedir" düşüncesine öğretmenlerin \%53.4'ünün katıldığ $\breve{1}_{1} \% 17.8$ 'inin katılmadığ $\breve{1}_{1} \% 5.5$ 'inin kesinlikle katıldığ 1 , \%4.1'inin ise kesinlikle katılmadığ $\breve{1}$ tespit edilmiştir. Öğretmenlerin \%19.2'sinin bu düşünceye katılma konusunda kararsız oldukları belirlenmiştir. Siyer dersi ile öğrencilerin Hz. Muhammed'in hayatını örnek alabileceğine ilişkin öğretmen görüşleri incelendiğinde, "Siyer dersi programı öğrencilerin Hz. Muhammed'in hayatını örnek alma konusunda etkili olabilecek düzeydedir" düşüncesine öğretmenlerin \%41.1'inin katıldığı, \%21.9'unun katılmadığı, \%8.2'sinin kesinlikle katıldığı ve \%5.5'inin kesinlikle katılmadığı tespit edilmiştir. Öğretmenlerin \%23.3'ünün bu düşünceye katılma konusunda kararsız oldukları belirlenmiştir. Siyer dersi ile Hz. Muhammed'in hayatının ayrıntılı olarak tanınacağına ilişkin öğretmen görüşleri incelendiğinde, “Siyer dersi programı öğ- 
rencilerin Hz. Muhammed'in hayatını ana hatlarıyla tanımalarını sağlamaktadır" düşüncesine öğretmenlerin \%65.8'inin katıldığ1, \%27.4'ünün kesinlikle katıldığ 1 \% \% 2.7'sinin ise katılmadığı tespit edilmiştir. Öğretmenlerin \%4.1'inin bu düşünceye katılma konusunda kararsız oldukları belirlenmiştir. Siyer dersi ile Hz. Muhammed'in hayatının ana hatları ile öğrenebileceğine ilişkin öğretmen görüşleri incelendiğinde, “Öğrencilerin çoğu Hz. Muhammed'in hayatını genel hatlarıyla öğrenebilmektedir" düşüncesine öğretmenlerin \%49.3'ünün katılmadığı, \%20.5'inin katıldığı, \%11'inin kesinlikle katılmadığ1 ve \%2.7'sinin kesinlikle katıldığı tespit edilmiştir. Öğretmenlerin \%16.4'ünün bu düşünceye katılma konusunda kararsız oldukları belirlenmiştir. Siyer dersinde Hz. Muhammed'in hayatının anlatılmasında bazı sorunlar olduğuna dair öğretmen görüşleri “Siyer dersinde Hz. Muhammed'in hayatını anlatma hususunda bazı sorunlarla karşılaşılmaktadır" düşüncesine öğretmenlerin \%30.1'inin katıldığı, \%34.2' sinin katılmadığı, \%11'inin kesinlikle katılmadığı, \%1.4'ünün ise kesinlikle katıldığı tespit edilmiştir. Öğretmenlerin \%23.3'ünün bu düşünceye katılma konusunda kararsız oldukları belirlenmiştir.

\section{Tartışma}

Öğretmenlerin siyer dersi ile ilgili programın amaçlarına ilişkin görüşleri değerlendirildiği zaman, öğretmenlerin siyer dersindeki konuların anlaşılır olduğu, bunun yanında dersin diğer dersler ve çevre ile uyumunun yüksek olduğu düşüncelerine çoğunlukla katılmadıkları belirlenmiştir. Amaçlara ulaşma konusunda siyer ders saatlerinin yetersiz olduğu ve amaçların iyi belirlenmemesinin istenen amaçlara ulaşma konusunda sıkıntı yarattığı düşüncelerine katılan ve katılmayan öğretmenlerin oranının birbirine yakın olduğu sonucuna ulaşılmıştır. Bunlara ek olarak, siyer ders programının açık ve anlaşılır bir dille ifade edildiği, siyer dersinin amaçlarının öğrencileri geliştirme konusunda yeterli olduğu, mevcut ders programının temel amaçları gerçekleştirmek için yeterli olduğu, siyer dersinin amaçlarının tam olarak gerçekleştiği, okul, aile, çevresel faktörler ve özel öğretim yöntemlerinin kullanılmasının amaçlara ulaşmada etkili olduğu, eğitim araç ve gereçlerinin yetersizliğinin amaçlara ulaşma konusunda önemli bir engel olduğu, uygulanan müfredatın ders hedefleri ile tutarlı olduğu ve siyer ders programının Hz. Peygamberin hayatını örnek alacak bilinçli bireyler yetişmesine yönelik hazırlandığı 
düşüncelerine öğretmenlerin çoğunluğunun katıldığı tespit edilmiştir. Elde edilen bulgulara göre, öğretmenlerin programın amaçlarına ilişkin görüşlerinin genellikle olumlu olduğu söylenebilir. Ancak ders saatlerinin yeniden düzenlenmesi, ders konularının daha anlaşılır olması ve derslerin çevre ile uyumlu olarak yapılması konusunda gerekli önlemlerin alınması gerekmektedir. Çünkü araştırmaya katılan öğretmenlerin çoğunluğunun bu konularda olumsuz düşüncelerinin olduğu görülmüştür.

Araştırmaya katılan öğretmenlerin ders içeriklerinin yeniden düzenlenmesi gerektiği düşüncesini desteklemelerinin temel nedeni, öğrencilerin bulundukları okul ve sınıf düzeylerine göre dini eğitimi algılama farklılıkları olabilir. Nitekim dini nitelikli eğitimlerin öğrencilerin yaş, sınıf ve ilgi düzeylerine göre farklılaştığı, öğrencilerin hazır bulunuşluk düzeylerinin de dini eğitimin içeriğini etkilediği bilinmektedir. Bunun yanında din eğitiminde de programın amaçlarının iyi belirlenmesi gerektiği ve verilecek eğitim ile öğrencilerde ne tür davranış değişikliklerinin beklendiğinin iyi tasarlanması gerekmektedir (Tosun, 2002, s.120). Çünkü dini eğitimde hedef ve amaçların iyi tasarlanması öğrenme öğretme sürecini de etkileyen bir unsurdur (Altaş, 2001, s.109). Ayrıca dini ders programlarının içeriklerinin hazırlanması da öğrencilerin içinde yaşadıkları dünyanın da göz önünde bulundurularak program hazırlanması belirlenen amaçlara ulaşmayı kolaylaştıracağı (Aydın, 2004, s.67), bunun sonucunda öğrencinin dini duyguları benimseme düzeyinin artacağ belirtilmektedir (Şentürk, 2013, s.158).

Öğretmenlerin siyer dersinde program içeriğine ilişkin düşünceleri incelendiği zaman, öğretmenlerin çoğunluğunun siyer dersinde yer alan müfredatın öğrencilerin yaş gruplarına uygun olduğunu, programda temel öğretim ilkelerine dikkat edildiğini, siyer dersinin öğrencilerin eleştirel ve akılcı yaklaşımların geliştirdiği, siyer dersine yeni ünite ve konuların eklenmesi gerektiği, dersin görsel eğitim yöntemlerinin etkili kullanılmasına olanak sağladığı, ders programının sözel yöntemlerin etkili kullanılmasına katkı sağladığı, siyer dersinin haftalık ders saatinin yeterli olduğunu düşündükleri, dersler işlenirken ders hakkında yeterli araç ve gereç temin edilebildiği, bunun yanında öğretmenlerin mevcut araç ve gereçleri etkili kullanabildikleri, ders programının öğrencilerin derse olan ilgilerini arttırdığı, ders programının öğrencilerin tüm ihtiyaçlarına cevap verebileceği ve öğrencilerin ahlaki gelişimlerini destekleyeceği, siyer programının ortaokul ve liselerde okutula- 
bilecek bir müfredata sahip olduğu düşüncelerine katıldıkları tespit edilmiştir. Elde edilen bu bilgilere göre, öğretmenlerin siyer dersine ilişkin düşüncelerinin genel olarak olumlu olduğu söylenebilir.

Araştırmaya katılan öğretmenlerin siyer dersine ilişkin eğitim ve öğretim süreci hakkındaki düşünceleri incelendiği zaman, siyer dersindeki öğretim ilkeleri arasında bazı çelişkiler bulunduğu, içerik ve ünitelerin birbirine paralel olarak hazırlandığı, siyer ders programının güncel ve yaşanan olaylara uygun olarak hazırlandığı, ders programının belirtilen süreler içerisinde bitirilebileceği ve ders programının öğrencilerin farklı kaynaklara temasını sağlayacağı düşüncelerine öğretmenlerin büyük bir çoğunluğunun katıldığı, bu düşüncelere katılmayan öğretmenlerin oranının düşük düzeyde olduğu tespit edilmiştir. Siyer dersinin öğreticilere tanıtılması hususunda ek eserlerin, örnek ders işlenişlerinin hazırlanması faydalı olmuştur düşüncesine ise öğretmenlerin çoğunluğunun katılmadığ tespit edilmiştir. Elde edilen bu bulgulara göre öğretmenlerin siyer dersinin eğitim ve öğretim sürecine ilişkin görüşlerinin genellikle olumlu olduğu, buna karşılık siyer eğitiminde kullanılan eserlerin öğreticilere tanıtılması için yeni önlemlerin alınması gerektiği söylenebilir.

Araştırmaya katılan öğretmenlerin siyer dersinin ölçme ve değerlendirme süreçlerine ilişkin görüşlerine göre, uygulanan ölçme ve değerlendirme yöntemlerinin program amaçlarına uygun değerlendirmeleri yeterli düzeyde yaptığı, siyer dersinin Hz. Peygamberin hayatını örnek alabilecek düzeyde etkili olduğu, ders programının Hz. Peygamberin hayatın ana ve genel hatları ile öğrenebilecekleri düzeyde bulunduğu düşüncesine öğretmenlerin büyük bir bölümünün katıldıkları tespit edilmiştir. Ancak öğretmenlerin mevcut ders programının Hz. Peygamberin hayatını anlatmada bazı sorunlar ortaya çıkardığı düşüncesine çoğunlukla katılmadıkları tespit edilmiştir. Elde edilen bu bulgulara göre öğretmenlerin siyer dersinin ölçme ve değerlendirme süreçlerine ilişkin düşüncelerinin genellikle olumlu yönde olduğu söylenebilir. Din kültürü ve ahlak bilgisi derine giren öğretmenler üzerinde yapılan çalışmalarda da öğretmenlerin ölçme ve değerlendirmeye ilişkin tutum ve görüşlerinin genellikle olumlu ve yüksek yüzeyde olduğu belirtilmiştir (Gündoğdu, 2011, s.190).

Dini eğitimlerin öğrencilerin sadece bilişsel değil, aynı zamanda duyuşsal özelliklerini de geliştirdiği bilinmektedir. Aynı zamanda din eğitimi ile kişinin dini açıdan kendini gerçekleştirme düzeyi de gelişmektedir (Tosun, 2002, 
s. 129-139). Ayrıca Hz. Peygamberin hayatının gerçekçi kimliğinin ve yaşamının doğru aktarılması din eğitiminin hedefleri arasında yer almaktadır. Bunlara ek olarak, din kültürü ve ahlak bilgisi kitaplarının içeriği de dini eğitimi sosyal ve fiziksel çevreye uyumlu bir biçimde işlemeyi amaçlayarak oluşturulmuştur. Bu kapsamda siyer eğitiminde Hz. Peygamberin hayatının ayrıntılı olarak anlatılmasının öğrencilerin hayatlarında Hz. Peygamberi örnek alma konusunda önemli değişiklikler meydana getireceği açiktır. Zaten eğitimin temel amaçlarından birisinin de öğrencilerin kişiliğini beslemek ve davranışlarına yön vermektir (Gürler, 2011, s.1). Hz. Muhammed'in hayat1, seçmeli ders olmadan önce de din kültürü ve ahlak bilgisi kitaplarında öğrencilerin her dönem görmüş oldukları konuların başında gelmiştir (Ev, 2010, s.159). Öğretmenlerin programın ölçme ve değerlendirme yapısına ilişkin düşüncelerinin genellikle olumlu yönde olması, siyer ders müfredatının din eğitimi esaslarına göre düzenlendiğini göstermektedir. Çünkü amaçlara ulaşılma düzeyinin çeşitli yöntemlerle test edilmesi ve değerlendirilmesi din eğitiminin temel amaçları arasında yer almaktadır (Aydın, 2004, s.3).

\section{Sonuç}

Sonuç olarak, siyer dersinin amaçları, içeriği, öğretme-öğrenme süreçleri ve ölçme değerlendirmeye ilişkin öğretmen görüşlerinin genel olarak olumlu yönde olduğu belirlenmiştir. Bunun yanında öğretmen görüşlerine göre programın amaçları, öğretme-öğrenme süreçleri ve ölçme-değerlendirme süreçlerine ilişkin bazı düşüncelerinin olumsuz yönde olduğu tespit edilmiştir. Bu bağlamda siyer dersinin belirlenen amaçlara ulaşabilmesi için programın yeniden düzenlenerek mevcut eksikliklerin giderilmesi gerektiğini söyleyebilir. Araştırmada elde edilen bulgular ışığında şu önerilerde bulunulabilir;

\section{Öneriler}

Siyer dersine ilişkin öğretmen görüşleri daha büyük örneklem grupları ile yapılan çalışmalarla incelenebilir. Böylece programın içeriği ve işleyişine ilişkin daha sağlıklı değerlendirmeler yapılabilir. 
Siyer dersine ilişkin öğrenci görüşlerinin ele alındığı çalışmalar yapılabilir. Böylece öğrencilerin dersten aldıkları verimin belirlenmesi, öğrencilerin gözünden ders müfredatı ve işleyişine ilişkin sorunların gözlenmesi mümkün olabilir.

Siyer dersinden öğrencilerin yüksek düzeyde verim almaları, dersin içeriği, öğretme-öğrenme süreçleri ve ölçme-değerlendirme süreçlerinin hangi yollarla geliştirileceğine dair öğretmen, veli, yönetici ve öğrenci görüşleri allnabilir. 


\title{
EXTENDED ABSTRACT
}

\section{Evaluation of Siyer Course Teaching Program}

\author{
Gizem Saygil1 - Fatma Songur \\ Karamanoğlu Mehmet Bey University-Religious Affairs Directorate
}

Along with the new education and training system $(4+4+4)$, important changes and innovations have occurred in the education system in our country. The first of these changes is the addition of new elective courses to the curriculum. However, it is seen that the research findings that contain the opinions of the teachers regarding the functioning and content of the new education system are limited. Especially, knowing the content, objectives, education-training process and measurement and evaluation structure of the siyer course, which is one of the elective courses brought by the new education system, and determining the disruptions in the course of the course are of great importance in determining the level of achieving the objectives of the course. For this reason, the necessity of determining the opinions of the teachers regarding the siyer lesson emerged.

The purpose of this research is to evaluate the siyer lesson, which is one of the elective courses brought by the new education and training system, from the perspective of teachers. In this context, the aim of the study was to examine the teachers' views about the objectives of the program, the content of the program, the learning-teaching process of the program and the assessment and evaluation features. Examining the innovations in the education and training system and determining the deficiencies brought by these innovations are very important for the system to work in accordance with its objectives. The evaluation of both the content and the teaching style of the siyer lesson, which affects the moral and religious understanding of the students, is necessary to support the moral and religious development of the students. In this context, this research was found to be important, as it will both provide resources to the literature and reveal its place in the curriculum.

In this research, " field research " method, which is frequently used in scientific research and education, has been used. Field research in the field of 
education is often used to describe teachers' views on some events or phenomena (viewpoints on lesson topics, views on how the topics are handled, points of view and solutions to problems within the education and training system). In the research, "scanning" model was used as a model and likert type scale was used for data collection. It is frequently used in the field of education in surveys conducted with Likert type scales. At the same time, research based on screening model is frequently used in social sciences in order to determine the characteristics related to a particular subject in the light of some variables (educational status, marital status etc.).

The universe of the research consists of teachers working in middle and high schools in Isparta city center in 2014 , as well as attending a siyer class. A total of 73 teachers attending the secondary school, imam hatip secondary school, high school and imam hatip high schools at the same time attending the siyer classes participated in the study. It is stated in the literature that some methods are used in the selection of samples from the universe. However, the higher the level of sampling is chosen from the universe, it was stated that the findings obtained would allow for a more effective generalization on the universe. In this context, some studies aiming to reach all individuals in the universe in the field of education have been conducted. In this study, the criterion sample selection model was not used and all teachers forming the universe were reached.

As the data collection tool in the research, the adapted version of the questionnaire related to "Evaluation of Religious Culture and Moral Education Curriculum" developed by Çınar (2005, p.156-159) was used. The applied questionnaire consists of two parts. In the first part, there are 10 questions aiming to determine the demographic characteristics of the teachers participating in the research. In the second part, there are 37 questions aiming to determine the thoughts of the teachers regarding the siyer lesson. The questionnaire, which consists of 37 questions and evaluates teachers' opinions about the siyer lesson, is a 5-point Likert-type questionnaire. The increase in the scores obtained from the questions shows that the participation rates of the teachers in the said thought also increased, and the low scores obtained indicate that the participation rates of the teachers in these thoughts are low. In addition, the questionnaire includes questions about 4 dimensions for the siyer lesson. Questions 1, 2, 3, 4, 5, 6, 7, 8, 9, 10, 11, 12 and 36 are the objectives of the program, 15, 16, 17, 21, 22, 24, 25, 26, 27, 29, 33 and 35 questions consist 
of the content of the program, 13, 14, 19, 20, 23 and 32 questions consist of the education and training process, and 18, 28, 30, 31 and 34 questions consist of the measurement and evaluation process of the program.

Percentage and frequency analyzes were used in SPSS 22.0 for Windows program for statistical analysis of the data obtained in the research. As a result of the research, it was determined that the opinions of teachers about the goals, content, teaching-learning processes and assessment of assessment were generally positive. As a result, $\mathrm{Hz}$. It can be said that Muhammad's life lesson has the necessary competence in terms of purpose, content, learning-teaching process, measurement and evaluation processes.

\section{Kaynakça / References}

Altaş, N. (2001), İlköğretim din kültürü ve ahlak bilgisi öğretimi. Ankara: Nobel Yayın Dağttım. 109-159.

Aydın, M., Z. (2004). Din öğretiminde yöntemler. Ankara: Nobel Yayın Dağıtım,3-67. Can, A., (2014), SPSS ile bilimsel araştırma sürecinde nicel veri analizi. Ankara: Pegem Akademi. Yayıncilık, 8-98.

Çınar, F. (2005). lköğretim din kültürü ve ahlak bilgisi öğretim programının değerlendirilmesi üzerine bir araştırma:Isparta Örneği.Yayımlanmamış Yüksek Lisans Tezi), Süleyman Demirel Üniversitesi, Isparta, 156-159.

Çınar, İ. (2003). Eğitimde Atatürkçülük ve örtük program. Ĕğitişim Dergisi, 3, 1-3. Demirel, Ö. (1992), Türkiye'de program geliştirme uygulamaları. Hacettepe Üniversitesi Ĕ̆itim Fakültesi Dergisi, 7, 27-43.

Ev, H. (2010). İlköğretim din kültürü ve ahlak bilgisi dersi öğretim programı hakkında bir değerlendirme. DEÜIF Dergisi, XXXII, 139-167.

Gündoğdu, Y. B. (2011), İlköğretim din kültüurü ve ahlak bilgisi öğretmenlerinin öğrenci başarısını değerlendirme yeterlikleri:İstanbul örneği, Yayınlanmamış Doktora Tezi, İstanbul Üniversitesi Sosyal Bilimler Enstitüsü, İstanbul, 32.

Gürler, Z. (2011), Dini-Tasavoufi Türk Edebiyatı öğretiminin ders kitabı, öğrenci ve öğretmen açısından değerlendirilmesi, Yayınlanmamış Doktora Tezi Gazi Üniversitesi, Sosyal Bilimler Enstitüsü, Ankara, 1.

Kalaycı, Ş. (2008). SPSS uygulamalı çok değişkenli istatistik teknikleri, 3. Baskı, Ankara: Asil Yayınları.

Karadă̆, E. (2010). Eğitim bilimleri doktora tezlerinde kullanılan araştırma modelleri: nitelik düzeyleri ve analitik hata tipleri. Kuram ve Uygulamada Eğitim Yönetimi, 16(1), 49-71. 
Kuş, D. (2009), İlköğretim programlarının, örtük programın ve okul dışı etmenlerin değerleri kazandırma etkililĭ̆inin 8. sinıf ilköğretim öğrencilerinin ve öğretmenlerinin görüşlerine göre incelenmesi. Yayımlanmamış Yüksek Lisans Tezi, Yıldız Teknik Üniversitesi, Sosyal Bilimler Enstitüsü, İstanbul.

Şentürk, H. (2013). Din psikolojisine giriş. İstanbul: İz Yayıncllık. 74-158.

Tosun, C. (2002). Din eğitimi bilimine giriş. Ankara: Pegem Akademi Yayıncllk, 6-120.

Tursun, H. K. (2011), Hz. Peygamber'in hayatın konu alan çocuk kitaplarındaki tarihi bilgilerin değerlendirilmesi. Yayımlanmamış Yüksek Lisans Tezi, Ankara Üniversitesi, Sosyal Bilimler Enstitüsü, Ankara.

Yıldırım, F. ve Öztürk B. K. (2009). Türkçe dersi öğretim programının ölçme değerlendirme ögesi hakkında öğretmen görüşleri. Çukurova Üniversitesi Eğitim Fakültesi Dergisi, 3(37), 92-108

\section{Kaynakça Bilgisi / Citation Information}

Saygılı, G. ve Songur, F. (2020). Siyer dersi öğretim programının değerlendirmesi. OPUS-Uluslararası Toplum Araştırmaları Dergisi, 15(24), 2615-2639. DOI: 10.26466/opus.658882 